\title{
Conflicts against Rajaji and his Ministry
}

\author{
S. Jeyakumar \\ Research Scholar, Department of History \\ V.H.N. Senthikumara Nadar College (Autonomous), Virudhunagar, Tamil Nadu, India
}

\section{OPEN ACCESS}

Manuscript ID:

ASH-2020-08013206

Volume: 8

Issue: 1

Month: July

Year: 2020

P-ISSN: 2321-788X

E-ISSN: 2582-0397

Received: 07.05.2020

Accepted: 18.06.2020

Published: 02.07.2020

Citation:

Jeyakumar, S. "Conflicts against Rajaji and His Ministry." Shanlax International Journal of Arts, Science and Humanities, vol. 8, no. 1, 2020, pp. 226-230.

DOI:

https://doi.org/10.34293/ sijash.v8i1.3206

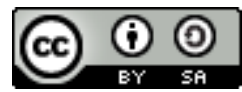

This work is licensed under a Creative Commons Attribution-ShareAlike 4.0 International License

\section{Abstract}

The political condition of Tamil Nadu, starting from 1946 to 1948, was unfavorable to the political hegemony of Rajaji, who confronted with multiple challenges and conflicts from the non-Brahmin leaders, particularly from the undisputed leader, Kamaraj and finally adjusted and co-operated with the congress party in all its endeavor. He had outwitted the prospects of Rajaji though he was a cunning, diplomatic, and elite of high order in the state. His power politics in the state ended in a fiasco. Being a Brahmin by descending, he was unable to command respect and gain solidarity from the general public. However, at the national level, he was respected, and his lofty ideals were heard and utilized by the national leaders such as Mahatma Gandhi, Pandit Jawaharlal Nehru, Sardar Vallabai Patel, Gulab Nabi Azad, etc.

Keyword: Conflicts, Rajaji, Ministry, New education policy, Half a day schooling, Rajaji's new education school, Opposition to the scheme and Opposition from dravidian parties

\section{Introduction}

Rajaji had confronted with issues one after another. After settling separate Andhra state issues, he was criticized for having accepted the governmental land of five acres for his service to the government as well as his involvement in the freedom movement. His party men had as that of others against Rajaji. They opposed Rajaji for receiving five acres of land from the government for his service as Governor-General of India. The party people stressed that if it was allowed to the high dignitaries, it should be sanctioned and extended to the poor freedom fighters in the state that had made sacrifices during the struggle for freedom. Sanjeevi Reddi, the leader of the congress party too in a political conference, openly criticized Rajaji for this attitude ${ }^{1}$. According to him, while some persons were rewarded with high offices like Governor, GovernorGeneral, and Minister, there was nothing wrong in the part of the Government, granting five acres of land or other help to the poor freedom fighters.

\section{New Education Policy}

Rajaji wanted to bring changes in the existing system of education, for it was upholding the tradition, philosophy, and old pattern. Hence he wanted to introduce certain changes in the curriculum so that the future generation would reap the benefits out of it. For this, he introduced certain changes in elementary school education. It was through the Director of Public Instruction of the composite state of Madras. ${ }^{2}$

The educational scheme of Rajaji and its origins from the proposals for educational reforms advocated by the Congress Party during the freedom movement. Besides, Gandhi sought emancipation in productive work in his basic education scheme, which was accepted by Rajaji, who wanted to implement it wholeheartedly. Rajaji, in principle, wanted to minimize the role of classroom teaching.

1 Justice Party Golden Jubilee Souvenir, 1968, P.21.

2 Souvenir, Viduthalai Kamaraj - A Decade of achievement, Chennai, 1961, P.14. 


\section{Half a Day Schooling}

While Rajaji was premier in 1937 , he suggested to R.M. Statham the then Director of Public Instruction implement a scheme of half a day schooling and half a day family apprenticeship. ${ }^{3}$ By that time, Statham though that the scheme was impractical since half a day school was not popular, as was indicated by the low attendance on Saturdays. However, he introduced the scheme in Periakulam Taluk in the Madurai district voluntarily, and the parents were given the option to register for half a day school or full-day school. It was found that no parent had opted for the half a day school, but preferred for a full day. ${ }^{4}$

When Rajaji came for the second term in 1952, he wanted to introduce a few changes in school education as that of his first term. After India attending freedom, he believed that only through Gandhi's idea of basic education growth of education might be achieved and believed that basic education in the alternative for the present system of primary education. However, through basic education was costly, the government of Rajaji had started 600 schools for basic education. Total primary schools in the Madras state was 38000. During Rajaji's regime in 1952, the double-shift system was in force in many urban primary and secondary schools were the rush for admission was great. During Omandur Ramasamy Reddiar ministry, a four-hour shifting system was introduced, and each shift had a separate set of teacher building was also used for two shifts in a place. The children also were free after school hours. Rajaji, therefore, proposed half-a-day schooling and a half-a-day family apprenticeship for primary schools in rural areas. ${ }^{5}$

3 Tamil Daily, Thinathanthi, Varalatru Suvadugal (Tamil), Chennai, 2010, P.7.

4 English Daily, Indian Express dated 25th April 1953, P.4.

5 "I do not like the alternative of cutting up the day into two halves. The school as well as the family occupation as should have the benefit of mornings as well as afternoons. The farmer boys and girls ought to go to school on three full days and get the benefit of it and be with the parents and cattle in the field of family workship during four full days." - Speeches of C. Rajagopalachari, Governor General of India, Government of India Publication, 1950, pp.257-259.

\section{Rajaji's New Education School}

- The scheme was meant only to non-basic primary schools in rural areas and not basic schools and primary schools in urban areas.

- The school hours of each would make a pupil in the primary school would be reduced to three hours a day. The working days were extended to six days a week.

- Every class would be divided into two batches, one batch would work for three hours in the morning and the other for three hours in the evening.

- The same teacher would handle both batches.

- The pupil had classroom work in a school for 20 to 24 periods per week as against 35 periods previously.

- There would be no lowering of standards in languages, elementary mathematics, history and geography, hygiene, civics, and moral instruction. The same number of periods would be provided for each of the subjects, and the same syllabus would be followed.

- The other half of the day, when the pupil would not be at school, would be spent by them helping their parents in their occupation if the parents belonged to occupational classes ${ }^{6}$.

- The pupil who did not belong to occupational classes would be attached to a farmer or craftsman in the village for learning a trade. Such a pupil would, for all purposes, work like apprentices under the craftsman. There would be no supervision by any school teacher. The craftsman will be the craft teacher and will be required to maintain an attendance register, indicating that the pupil was present during the allotted time.

- The pupil might be organized to render social services to the village in all possible ways.

- Where there was no local craftsman, it was necessary to induce one from outside to come and settle in the village in the vicinity of the school. Since he would require a place to serve as his work spot, a craft shed might be erected within the premises of the school if the school had a large compound. ${ }^{7}$

\footnotetext{
6 Rajmohan Gandhi, Op.Cit., P.24.

7 Ibid., P.29.
} 
- It was estimated that such special arrangements of craft education might be required by not more than 5 to 10 pupils of nonoccupational classes.

- A village school council consisting of willing and capable persons might be constituted in each village to help craft training.

- The scheme would come into effect from the school year 1953-54, commencing in June 1953.

The new education policy of Rajaji was aiming for a shift system in the schools to facilitate more children to get admission in the schools. However, the scheme provided only three hours of schooling and another three hours of apprenticeship in crafts. ${ }^{8}$ The new scheme was a proposal combing manual training of a pre-vocational with formal academic education. It was termed as 'Kulakkalvi' (vocational education) because the children were expected to receive vocational training from their parents who had been traditionally engaged in a specific profession.

\section{Opposition to the Scheme}

As the scheme or Rajaji was communal based, it was opposed both by educationalists and politicians. ${ }^{9}$ Despite the opposition, Rajaji refused to repudiate or rescind the scheme. He was stubborn in his decision despite the opposition. Meanwhile, a special general body meeting of the Madras Chamber of District Boards held at Madras passed a resolution against implementing it. Besides the district board, the Ambasamudram Taluk Elementary School Teacher's Conference, the Madras District Educational Conference, the Ramnad District Educational Conference, and the Madras State Headmaster's Conference were passed resolutions requesting the government to drop the scheme. Even the proRajaji English Daily, the Hindu through a cartoon, expressed its opposition to the scheme. O.P.R. criticized the scheme and warned Rajaji that there might be agitations against the scheme. Despite all, Rajaji was stubborn to his scheme and the strong opposition gaining momentum against his policy day by day. ${ }^{10}$

8 English Daily, Indian Express dated 16 June 1953, P.3.

9 English Daily, Indian Express dated 16 June 1953, P.3.

10 Nam Nadu, Tamil Daily, dated 19 June 1953, P. 3.

\section{Opposition from Dravidian Parties}

In opposing the new scheme, both the Dravidar Kazhagam and the Dravida Munnetra Kazhagam showed their strong protest. ${ }^{11}$ The D.M.K. Party observed 21 June 1953 as an Anti-New Elementary Education Scheme Day and conducted processions and launched signature campaigns against the scheme. ${ }^{12}$ Besides, the executive committee of the D.M.K. Party met on 13th July 1953 and passed resolutions against the new educational policy of Rajaji by picketing in front of Rajaji's house from 14 July 1953.

According to D.M.K. Party, the new educational policy of Rajaji was a clever device to perpetuate 'Varnashrama Dharma,' which would strike at the very root of the social and political progress of the backward classes. ${ }^{13}$ C.N. Annadurai, the leader of the D.M.K. Party, challenged Rajaji at the public meetings that he should either drop it or to resign.

The Dravida Kazhagam also criticized Rajaji with much vehemence and conducted meetings against him. Under the situation, though members of Congress opposed the scheme, they were not in a position to come out openly and criticized the attitude of Rajaji. However, they lent their moral support to the agitation. ${ }^{14}$ When the motion for the introduction of the new educational policy was introduced in the house, the opposition parties succeeded and forcing the government to refer the scheme to an expert committee. At last, voting was ordered in which the new scheme was defeated in the house.

The opposition members felt that they had defeated the government by defeating the educational scheme of Rajaji. Thennetti Viswanatham of the Prakasam group raised a point of order in the Assembly on 31 July 1953 in which he stated that under the spirit and terms of the constitution, the government could not continue in office and must tender its resignation. ${ }^{15}$

Following these turmoils, and conflicts in the state and political affairs of the Congress party,

11 Rao, P.R., History of Modern Andhra, Madras, 1978, P.44.

12 Ibid., P.49.

13 Senthil Selvan, Kalaignar Oru Kalai Ilakkiam, Tamil, Madras, 1970, P.19.

14 Sen, S.P., Dictionary of National Biography, Vol.III, Calcutta, 1974, P.72.

15 Ramachandran, S., Anna Speaks, Madras, 1975, P.19. 
there were rumors that Rajaji was anxious about relinquishing from office. His political enemies confirmed when he stayed away from the session of the legislative meeting due to indisposition. It was also rumored that he was contacting the All India Congress President Nehru over his retirement from active politics.

On confirming all these rumors, into reality, Rajaji himself conveyed to the Legislature Party on $26^{\text {th }}$ March 1954, that he took a decision to resign from the position of the office as well as the leader of the party and regretted to accept his resignation for further arrangements. ${ }^{16}$ In the meanwhile, Kamaraj and Rajaji met before the Legislative Congress meeting. They came to an understanding of which type of arrangements would be taken on the eve of his resignation from the office. Accordingly, Rajaji suggested that there need not be an election to the new party leader till the Budget session was over, and one of the ministers would act as chief minister in charge for one or two months. ${ }^{17}$ Further, Rajaji proposed C. Subramaniam as his successor for chief minister post for only two months only, and subsequently, new leaders would be elected. ${ }^{18}$ Since then, to avoid any controversy during budget sessions, Kamaraj accepted the offer of Rajaji. Besides the election of new leaders, Rajaji announced it suddenly without thinking of sufficient time and fixed March 30, 1954, just five days away as the date for an election. Rajaji insisted on the date despite protests from members to extend it. ${ }^{19}$ By making these arrangements, Rajaji, cut short the thinking of selecting a proper leader for the post and his nominee should be elected for the post.

Under the tight schedule and short notice, no proper candidate was selected to compete Rajaji's candidate C. Subramaniam. There was only one person, in the called A.B. Shetty, by name in the Rajaji's ministry was acceptable to the anti-Rajaji

16 Muruga Thanuskodi, Kamaraj Oru Charithram (Tamil), Madras, 1976, P.19.

17 Muruga Thanuskodi, Kamaraj - A History, Madras, 1975, P.48.

18 English Daily, Indian Express, dated 3rd April and 7th April 1954, P.3.

19 Muthusamy, A.S., Kamaraj, Political Study, Madras, 1988, P.61. group. ${ }^{20}$ In the meanwhile, A.B. Shetty did not like to contest the election due to short notice against the nominee of Rajaji. Under the compelling situation, the Kamaraj group insisted on Kamaraj in the election. But Kamaraj hesitates to contest the election toll the evening on that date, and Rajaji group thought of cake wake to their supporter C. Subramanian in the election. However, in the evening by 6 P.M. Kamaraj was compelled and was forced to file nomination for the post.

Due to the embarrassing situation, C. Subramanian pleaded the party men to postpone the election to some other date. Being a strude politician, Kamaraj did not agree for the postponement and referred high command to that it opposed any further postponement. The election meeting was attended by 134 members, P. Varadarajulu Naidu proposed Kamaraj against Rajaji's candidate C. Subramanian. It was seconded by Annamalai Pillai. ${ }^{21}$ Namasivayam, M., Kamaraj Varalaru (Tamil), Madurai, 1963, P.39. Bakthavasalam, the supporter of Kamaraj in the early days, proposed C. Subramaniam, and it was seconded by U. Krishna Rao. In the election, Kamaraj secured 93 votes against 41 votes of C. Subramaniam.

Soon after the election was over, Kamaraj wrote the All India Congress President Nehru about the election results. Following that, Kamaraj went to Delhi in April 1954 and suggested to the high command that he was ready to function as the head of the party till the new chief minister's appointment by the party high command. ${ }^{22}$ In reply to him, the party high command stated that the leader of the party should be the chief minister, and Kamaraj was accepted as the new chief minister of Madras state. ${ }^{23}$ However, the friends of Kamaraj expedited the problems that arose during the new election and suggested to him that he should occupy the post. While accepting the offer, Kamaraj asked his friends to allows him to administer the state independently without giving any hindrance. Besides, he got the promise of selecting the ministers freely. With all their co-operation and goodwill of the party 20 English Daily Indian Express dated 3rd April and 7th April 1954, P.1.

21 Namasivayam, M., Kamaraj Varalaru (Tamil), Madurai, 1963, P.39.

22 English Daily The Mail dated 3rd April 1954, P.3.

23 English Daily dated Indian Express, 7 April 1954, P.1. 
men and committee members, Kamaraj took the administration as the chief minister of Tamil Nadu and put an end to the speculation following Rajaji's decision to relinquish leadership. ${ }^{24}$

With the acceptance of Kamaraj as the chief minister of the statemates and all the speculations prevailed were ended and the Governor accepted the resignation of Rajaji on 13, 15 April 1954, and the swearing-in of the new ministry took place on April 14, 1954, the Tamil New Years Day.

C. Raja Gopalachariar, popularly known as Rajaji, administered the state from 1952-1954 amidst of political conflicts and turmoils within the party and outside from his political rivals and opposition parties. Being a shrude and clever politician, he knows pretty well about the situations and political nature of the people of Tamil Nadu and simply repudiated the interest shown by the party. At the same time, the state congress got the majority in the 1957 elections. Though the Congress party received an individual majority, in the state, it could not get the overall majority in the state to form the ministry. ${ }^{25}$ Viewing the political situation of the state, he showed his reluctancy to head the ministry. Under the piquant situation, to get the co-operation 24 Kapur, R.P., Kamaraj an Iron Man, New Delhi, 1966, P.18.

25 Chokkalingam, T.S., Kamaraj, Madras, 1955, P.38. of party high command, state leaders, party people, and opposition front, he shared diplomatic posture of unwillingness to form the ministry. However, he was successful in his attempt to getting all their support and markedly steered the ministry. Being an elite the tackled all the intra-party crisis and problems in the state in an amicable way. ${ }^{26}$

\section{Conclusion}

In the meantime, people anticipated more reforms and economic measures from him. However, his educational policy and separate Andhra state, politics earned displeasure from the people, who rose against his to change the leadership. All the non-Brahmin political leaders and the general public rose against him. Anticipating the grave situation in the party as well as in the CLP, he appealed the party high commandant to change the leadership and to accept his resignation on the health ground. ${ }^{27}$ It was quite obvious and apparent that he could not arrest the onward march of the emerging leader Kamaraj and his mass background of the non-Brahmin Congress Party and, at last, made his way to the emergence of Kamaraj.

26 Copey, A.R.H., The Political Career of Rajagopalachariar, 1937 - 1954, Madras, 1978, P.53.

27 Ibid., P.59.

\section{Author Details}

S. Jeyakumar, Research Scholar, Department of History, V.H.N.Senthikumara Nadar College (Autonomous), Virudhunagar, Tamil Nadu, India. 